\title{
p16 ink4a Is a Surrogate Marker for High- Risk and Malignant Cervical Lesions in the Presence of Human Papillomavirus
}

\author{
S. Lakshmi ${ }^{\mathrm{a}}$ P. Rema ${ }^{\mathrm{b}} \quad$ Thara Somanathan $^{\mathrm{c}}$ \\ Divisions of a Molecular Medicine, ${ }^{b}$ Surgical Oncology and 'Pathology, Regional Cancer Center, \\ Thiruvananthapuram, India
}

\section{Key Words}

Cervical cancer $\cdot$ Human papillomavirus $\cdot$ In situ

hybridization $\cdot p 16^{\text {ink4a }} \cdot$ Squamous intraepithelial lesions

\begin{abstract}
Objective: To strengthen the role of high-risk human papillomaviruses (HPVs) in the development of cervical cancer, and the association between HPV and the cell cycle inhibitor gene $16^{\text {ink4a }}$ in cervical carcinogenesis. Methods: In this study, the association between p16 $6^{\text {ink4a }}$ and the presence of HPV DNA in cervical lesions was investigated in a total of 177 cervical biopsies classified as benign $(n=42)$, low-grade squamous intraepithelial lesions (LSIL; $n=34$ ), high-grade squamous intraepithelial lesions ( $\mathrm{HSIL} ; \mathrm{n}=48$ ) and invasive cancer $(n=53)$. p16 ink4a expression was analyzed by immunohistochemistry while HPV DNA was localized by in situ hybridization. Results: No significant association was found between $16^{\text {ink4a }}$ expression and HPV presence in benign and LSIL samples. In HSIL and invasive cancer, a significant association was found between $16^{\text {ink4a }}$ overexpression and the presence of HPV DNA. Conclusion: Immunohistochemical p16 ink4a expression is associated with HPV infection in HSIL and cervical cancer, suggesting a role of p16 as a biomarker of HPV-associated cervical lesions.
\end{abstract}

Copyright $\odot 2009$ S. Karger AG, Basel

\section{KARGER}

Fax +4161306 1234 E-Mail karger@karger.ch www.karger.com (c) 2009 S. Karger AG, Basel

$1015-2008 / 09 / 0763-0141 \$ 26.00 / 0$

Accessible online at:

www.karger.com/pat

\section{Introduction}

Human papillomavirus (HPV) is a definite etiological agent for cervical neoplasia [1]. Integration of high-risk HPV sequences into the cell genome causes disruption of the E2 gene and subsequent overexpression of viral E6 and E7 oncogenes that abrogate p53 and Rb tumor suppressor functions, respectively, and lead to loss of cell cycle control [2,3]. HPV is thus a sensitive marker for identifying patients at risk for cervical neoplasia. Detection of HPV subtypes in cervical lesions would be very useful in distinguishing patients at risk for progression to cervical neoplasia.

The $16^{\text {ink4a }}$ protein is a tumor suppressor protein that inhibits the cyclin-dependent kinases which phosphorylates the retinoblastoma protein. Overexpression of p16 ${ }^{\text {ink4a }}$ in cervical cancer is believed to be due to the inactivation of Rb by HPV E7 oncoprotein. Many groups of investigators have studied the expression pattern of p16 $6^{\text {ink4a }}$ in dysplastic squamous and glandular cervical tissue sections and smears [4-7]. p16 $6^{\text {ink4a }}$ is now widely accepted as a sensitive and specific marker of cervical squamous dysplastic cells and a valuable adjunct in cervical cancer screening. No data are however available for Indian cervical lesions regarding the association between p16 ${ }^{\text {ink4 }}$ and HPV status. India has over two thirds of the world's cervical cancer burden [8]. Together with the age-

Dr. S. Lakshmi

Division of Molecular Medicine

Regional Cancer Center

Thiruvanathapuram, Kerala 695011 (India)

Tel. +91 471252 2280, Fax +91 471255 2388, E-Mail rcc.lakshmi@gmail.com 
adjusted rate and ranking, the world pattern of cervical cancer clearly indicates that cervical cancer is predominantly a problem of poor socioeconomic status. Moreover, women in India have a higher life time risk to get cervical cancer, which is double the risk compared to the data worldwide.

In many countries, HPV testing has already been incorporated into screening programs generally as an adjunct to existing cytologic screening programs. Among the methods used for the detection of molecular markers, in situ hybridization (ISH) offers the unique advantage of visualizing and even quantifying clinically relevant molecules in a morphological context [9]. The application of nucleic acid targeting and signal amplification technologies to ISH has helped out detection of as few as one or two copies of DNA molecules [10]. The purpose of the present study was to provide data from India to strengthen the association between p16 $6^{\text {ink4a }}$ and the presence of HPV in high-grade cervical lesions and cervical cancer tissue. In addition, it is also attempted to emphasize the importance of the ISH technique in the detection of HPV infection in clinical samples.

\section{Patients and Methods}

\section{Patient Samples}

Cervical tissue samples were obtained from patients attending the Surgical Oncology Clinics of the Regional Cancer Center, Thiruvananthapuram. The study was approved by the Institutional Review Board and Ethical Committee of the Regional Cancer Center. Biopsies were collected during colposcopic examination or loop electrosurgical excision procedures. Benign cervical tissue samples were obtained from patients undergoing hysterectomy for non-malignant conditions. Tissues were fixed in $10 \%$ buffered formalin and embedded in paraffin wax. Five-micrometer-thick sections were cut and stained with hematoxylin-eosin for histological examination. A total of 177 tissue samples were analyzed, including 42 benign cervical tissues, 34 low-grade squamous intraepithelial lesions (LSIL), 48 high-grade squamous intraepithelial lesions (HSIL) and 53 invasive cervical cancer samples.

\section{p16 ink4a Immunohistochemistry}

Serial sections were taken from each sample. Immunohistochemistry was done using mouse monoclonal anti-p16 antibody (Novocastra, UK) and a supersensitive polymer-HRP immunohistochemical detection system (Biogenex, USA). Briefly, sections were deparaffinized in xylene and then rehydrated through graded series of alcohol. Antigen retrieval was performed by heating the sections in $10 \mathrm{mM}$ citrate buffer ( $\mathrm{pH} 6.0)$ in a microwave oven. Endogenous peroxidase activity was blocked by incubating sections in $0.3 \%$ hydrogen peroxide in methanol for $20 \mathrm{~min}$. After blocking non-specific binding by incubation with 3\% BSA, primary antibody was added and incubated for $1 \mathrm{~h}$ at $37^{\circ} \mathrm{C}$. For detection, sections were incubated with super-enhancer solution for
$30 \mathrm{~min}$ followed by polymer-HRP conjugate for $30 \mathrm{~min}$ at $37^{\circ} \mathrm{C}$. The reaction product was visualized using diaminobenzidine as chromogen.

\section{Evaluation of Immunostaining}

p16 ${ }^{\text {ink4a }}$ immunostaining was considered positive when either nucleus or cytoplasm or both showed positive staining. The staining was scored as follows: negative ( $<1 \%$ positive), sporadic (isolated cells positive, $<5 \%$ ), focal ( $<25 \%$ of the cells positive) and diffuse ( $>25 \%$ cells were positive)

\section{HPV ISH}

Samples were analyzed for HPV DNA by ISH using HPV-biotinylated DNA probes (DakoCytomation, Denmark) and a tyramide signal amplification system (DakoCytomation GenPoint ISH Detection System). The sections were subjected to proteinase $\mathrm{K}$ digestion followed by heating in citrate buffer $(\mathrm{pH}$ 6.0) in a microwave oven. Biotinylated HPV DNA probe was added to the sections, and denaturation of the probe and target DNA was performed by heating at $95^{\circ} \mathrm{C}$ for $10 \mathrm{~min}$. The sections were incubated at $4^{\circ} \mathrm{C}$ overnight for hybridization. The slides were incubated in a stringent wash solution at $55^{\circ} \mathrm{C}$ for $30 \mathrm{~min}$. The bound probe was identified by incubation with the detection system which involves tyramide signal amplification, followed by visualization using diaminobenzidine as chromogen substrate. All samples were analyzed using a HPV wide spectrum probe followed by analysis of positive samples with type-specific probes (HPV 6/11, 16/18, 31/33/35)

\section{Evaluation of ISH Signal Patterns}

Cervical cancer cell lines SiHa and HeLa, known to contain HPV integrated into the cell genome, were used to standardize ISH. The ISH signal patterns were noted as nuclear dot-like or punctuate and nuclear diffuse positivity.

\section{Statistical Analysis}

The data were analyzed using SPSS statistical software. MannWhitney and Wilcoxon nonparametric tests were applied to compare immunohistochemical expression of p16 ink4a in various grades of cervical lesions. Fisher's exact test was used for comparisons between the histological groups for p16 $6^{\text {ink4a }}$ and HPV types. $p$ values were two sided, and the level of significance was set at 0.05 .

\section{Results}

Immunoexpression of $\mathrm{p} 16^{\text {ink4a }}$ and HPV ISH are summarized in table 1.

\section{p16 ink4a Immunoexpression}

p16 ${ }^{\text {ink4a }}$ expression was observed in both nucleus and cytoplasm with varying degrees of intensity. Representative expression patterns of $\mathrm{p} 16^{\text {ink4a }}$ in benign and LSIL samples are shown in figure 1 . Of the 177 cervical samples, p16 ${ }^{\text {ink4a }}$ distribution was negative in 43 (24.3\%), sporadic in 28 (15.8\%), focal in $10(5 \%)$ and diffuse in 96 
Fig. 1. p16 $6^{\text {ink4a }}$ immunostaining patterns showing sporadic expression in benign cervical epithelium (a, b), focal expression in LSIL (c-e) and diffuse expression in $\operatorname{LSIL}(\mathbf{f})$.
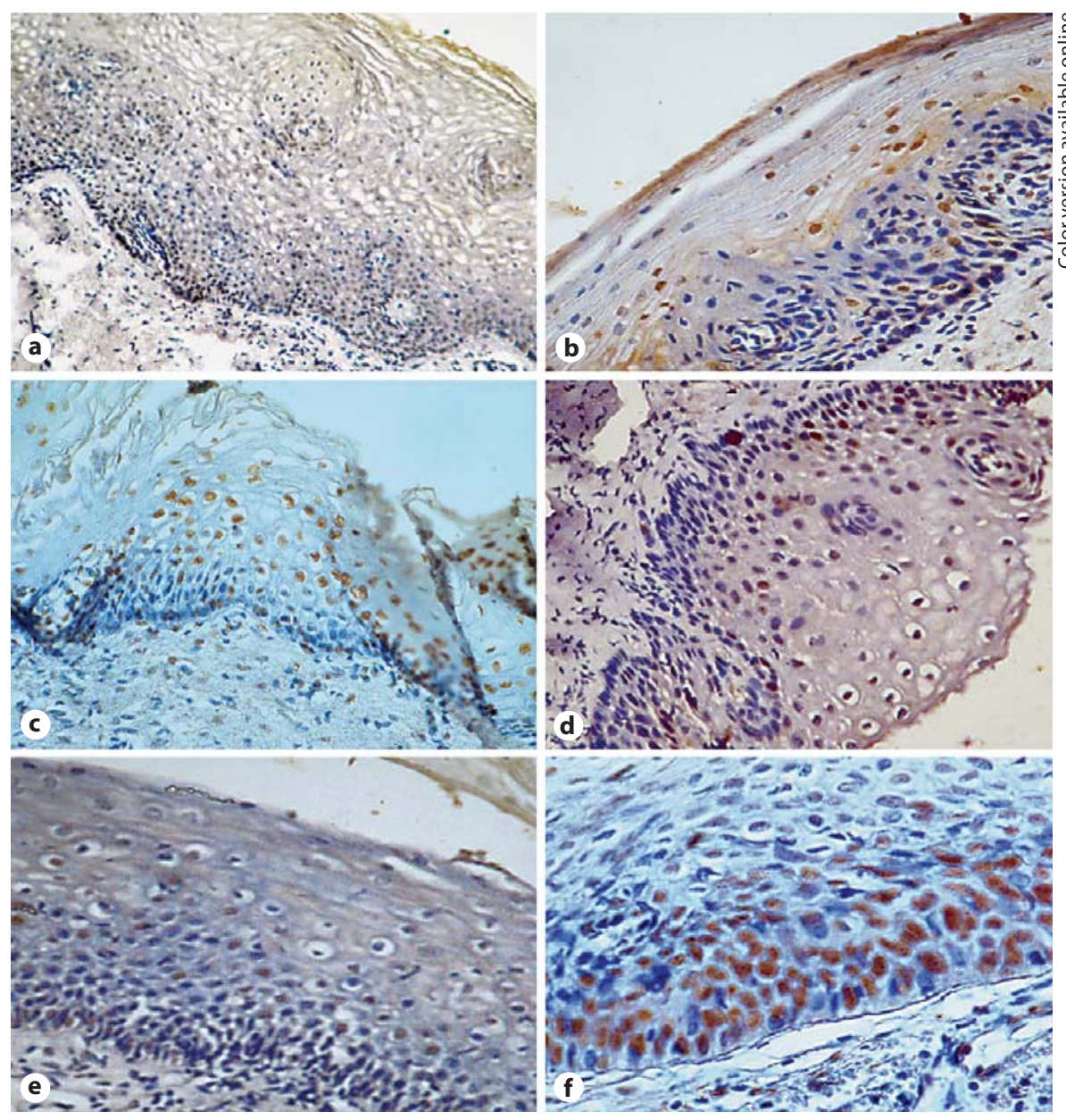

Table 1. Summary of cervical lesions evaluated by $16^{\text {ink4a }}$ immunohistochemistry and HPV ISH

\begin{tabular}{|c|c|c|c|c|c|c|c|c|c|c|}
\hline \multirow{2}{*}{ HPV type: } & \multicolumn{10}{|c|}{ p16 expression } \\
\hline Histology & \multicolumn{2}{|c|}{ negative } & \multicolumn{3}{|c|}{ sporadic } & \multicolumn{2}{|l|}{ focal } & \multicolumn{3}{|c|}{ diffuse } \\
\hline & neg. & $16 / 18$ & neg. & $6 / 11$ & $16 / 18$ & neg. & $16 / 18$ & neg. & $16 / 18$ & $31 / 33 / 35$ \\
\hline Benign & 31 & 0 & 10 & 0 & 0 & 1 & 0 & 0 & 0 & 0 \\
\hline LSIL & 6 & 0 & 11 & 3 & 0 & 7 & 0 & 7 & 0 & 0 \\
\hline HSIL & 2 & 1 & 2 & 0 & 1 & 0 & 2 & 7 & 33 & 0 \\
\hline Cervical cancer & 2 & 1 & 0 & 0 & 1 & 0 & 0 & 8 & 40 & 1 \\
\hline
\end{tabular}

(54.2\%) cases. In benign or non-neoplastic epithelium, $72.1 \%$ of the samples were negative and only 10 of 42 (35.7\%) showed sporadic staining. In the LSIL group, p16 ${ }^{\text {ink4a }}$ immunoreactivity was observed in 28 of 34 cases of which 14 were sporadic, 7 focal and another 7 with diffuse staining pattern. Figure 2 shows representative ex- pression patterns of $\mathrm{p} 16^{\mathrm{ink} 4 \mathrm{a}}$ in HSIL and cervical cancer samples. Of the 48 samples in the HSIL group, 45 showed positivity for p16 ${ }^{\text {ink4a }}$ and $88.8 \%$ showed a diffuse staining pattern. Positivity was seen in the lower two thirds of the squamous epithelium in the CIN 2 lesions and in the full thickness of the epithelium in CIN 3 lesions. Among 
Fig. 2. p16 $6^{\text {ink4a }}$ immunostaining patterns showing sporadic (a) and diffuse $(\mathbf{b}, \mathbf{c})$ patterns in HSIL, and sporadic (d), focal (e, f) and diffuse $(\mathbf{g}, \mathbf{h})$ patterns in invasive cervical cancer.
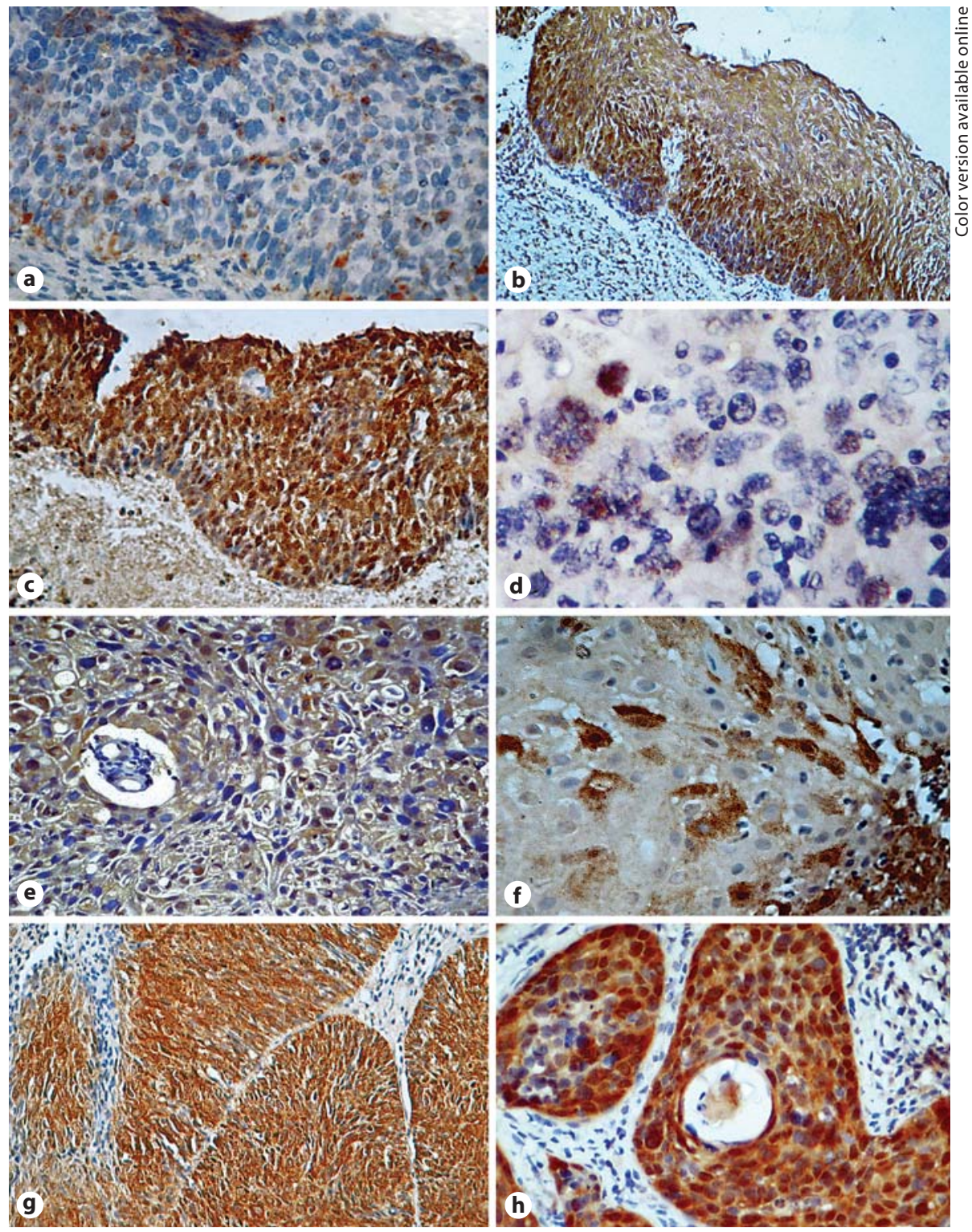

the malignant lesions, 50 of 53 were positive for $\mathrm{p} 16^{\text {ink4a }}$; $98 \%$ of these positive samples showed a diffuse pattern. Statistical analysis showed a positive correlation between p16 ${ }^{\text {ink4a }}$ immunostaining and histologic grade of the lesion $(\mathrm{r}=0.567, \mathrm{p}=0.000)$. The frequency of expression patterns of p16 $6^{\text {ink4a }}$ in various grades of cervical lesions studied is shown in table 2 .

\section{HPV ISH}

HPV ISH signals were observed as punctuate or dotlike nuclear positivity in the majority of cases while a few showed diffuse nuclear positivity along with punctuate positivity. Figure 3 shows the positive ISH signal patterns in various grades of cervical lesions: 87 out of 177 samples were positive for HPV wide spectrum probe. All of the benign lesions were negative for HPV. HPV DNA was seen in 47 malignant samples, 37 HSIL and 3 LSIL samples. Of HPV type-specific probes, 37 HSIL and 42 cancer cases were positive for the HPV type $16 / 18$ probe. Three of the LSIL were positive for the HPV type 6/11 probe while 1 of the malignant samples was positive for the HPV type 31/33/35 probe. The majority of samples showed ISH positivity as punctuate or dot-like signals while few showed diffuse nuclear positivity. The results showed a 


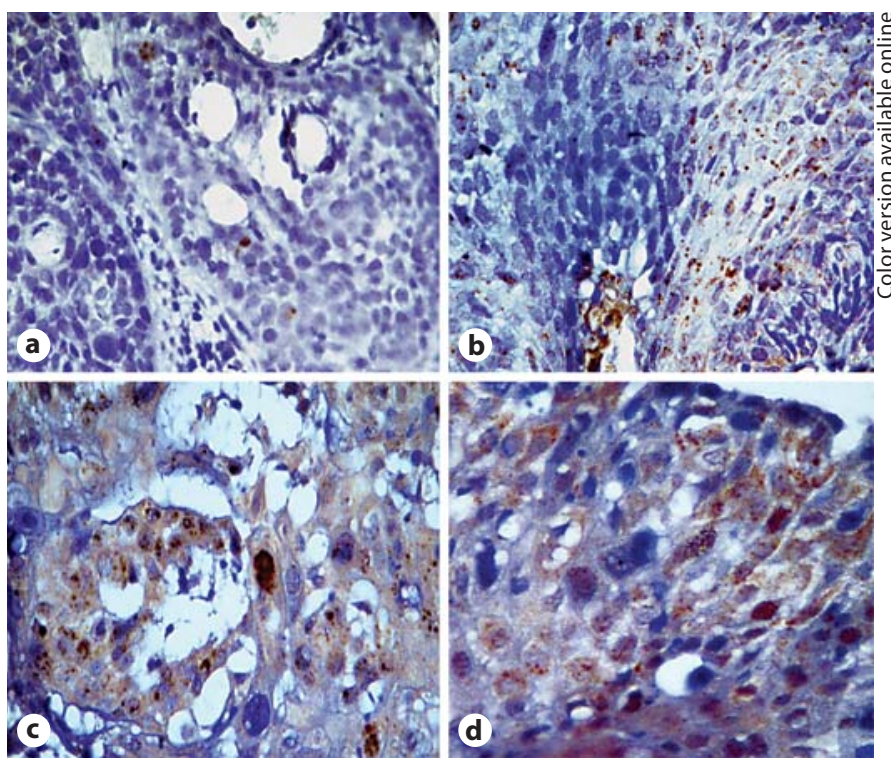

Fig. 3. HPV DNA detected by ISH. Representative samples showing punctuate signals $(\mathbf{a}, \mathbf{b})$ and a mixed pattern of punctuate and diffuse signals $(\mathbf{c}, \mathbf{d})$.

strong correlation with histologic grades of the lesions $(\mathrm{r}=0.751, \mathrm{p}=0.000)$.

p16 ${ }^{\text {ink4a }}$ immunoreactivity was compared with the HPV status of the individual samples. None of the benign lesions was positive for HPV. Forty-one cases were negative for both p16 ${ }^{\text {ink4a }}$ and HPV. Of the 96 cases which exhibited strong diffuse staining for $\mathrm{p} 16^{\text {ink4a }}, 22$ were negative for HPV and 73 were positive for high-risk HPV 16/18. Two samples which were HPV $16 / 18$ positive showed sporadic p16 $6^{\text {ink4a }}$ staining. Samples positive for HPV 6/11 showed sporadic p16 positivity and were of the LSIL group. None of the advanced lesions showed positivity for the HPV 6/11 probe. The results indicate a strong correlation between the presence of HPV 16/18 and strong/diffuse p16 $6^{\text {ink4a }}$ expression in HSIL and invasive cervical cancer tissue $(r=0.504, p=0.000)$. The frequency of results of p16 $6^{\text {ink4a }}$ immunohistochemistry and HPV ISH is graphically represented in figure 4.

\section{Discussion}

Molecular analysis of complex interactions of deregulated oncogenes with various cellular protein complexes has led to the identification of new biomarkers in dysplastic and neoplastic cells [11]. One such marker is the cy-

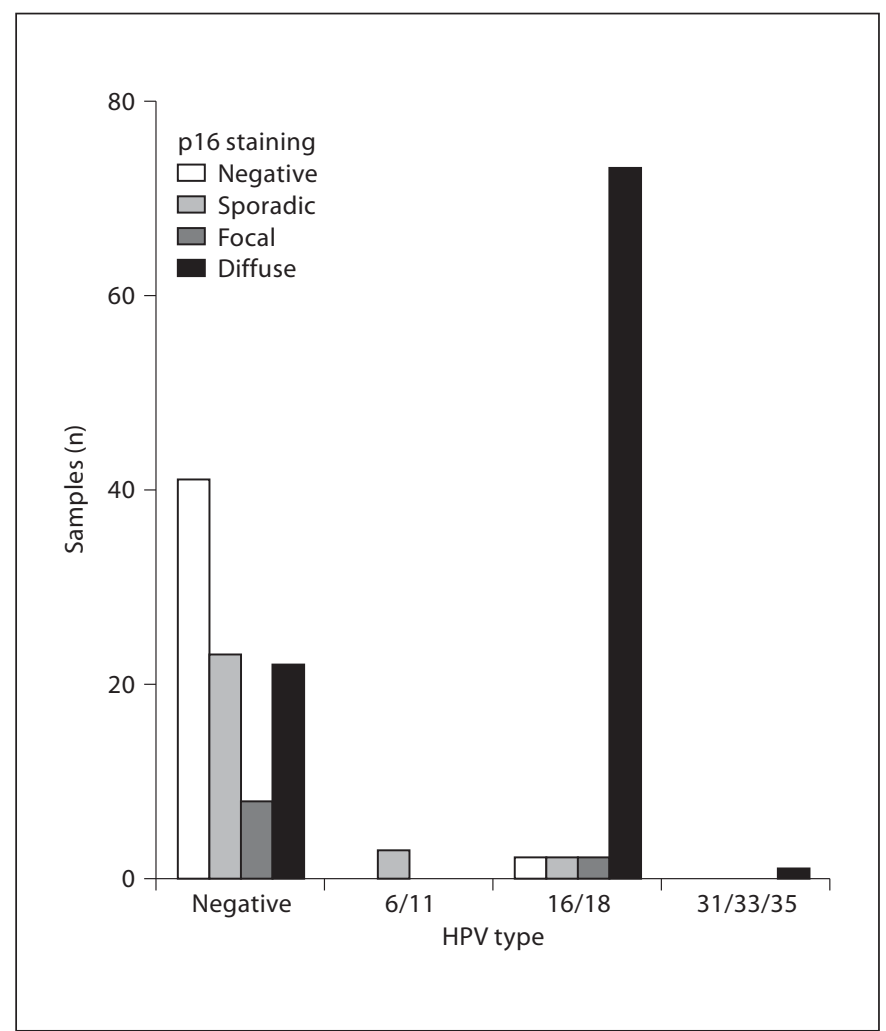

Fig. 4. Graphical representation of the association between p16 ${ }^{\text {ink4a }}$ immunoexpression and the presence of HPV DNA in various grades of cervical tissue samples.

Table 2. $16^{\text {ink4a }}$ immunohistochemical staining patterns in cervical lesions

\begin{tabular}{lccccc}
\hline Histology & \multicolumn{2}{l}{ p16 ${ }^{\text {ink4a }}$ expression } & & & Total \\
\cline { 2 - 5 } & negative & sporadic & focal & diffuse & \\
\hline Benign & 31 & 10 & 1 & 0 & 42 \\
LSIL & 6 & 14 & 7 & 7 & 34 \\
HSIL & 3 & 3 & 2 & 40 & 48 \\
Cervical cancer & 3 & 1 & 0 & 49 & 53 \\
\hline Total & 43 & 28 & 10 & 96 & 177 \\
\hline
\end{tabular}

clin-dependent kinase inhibitor p16 ${ }^{\text {ink4a }}$ in cervical cells, which may be responsible for the maintenance of the cell cycle and apoptosis. p16 ${ }^{\text {ink4a }}$ is a protein product of the cyclin-dependent kinase inhibitor 2 (CDK2) gene, which binds to and inhibits CDK4- or CDK6-mediated phosphorylation of $\mathrm{pRb}$ [12]. Abnormalities in the cell cycle 
regulatory machinery and disruption of cell cycle control are common features in many cancers. While some studies have reported $\mathrm{p} 16^{\text {ink4a }}$ overexpression to be related to cancer development [13-18], others have shown absence or low expression of $\mathrm{p} 16^{\text {ink4a }}$ with tumor progression [19$22]$. In the present study, p16 ${ }^{\text {ink4a }}$ positivity patterns were found to correlate with tumor progression in the cervical samples studied. Some studies on cervical cancer have demonstrated that $\mathrm{p} 16^{\text {ink4a }}$ may serve as a marker to differentiate neoplastic lesions from hyperplastic or reactive lesions $[5,23]$. In benign or non-neoplastic lesions, p16 ${ }^{\text {ink4a }}$ immunoexpression showed a sporadic pattern in positive cases while the majority of these lesions were negative.

HPV E6 and E7 proteins have been considered to be responsible for the malfunction of p16 ${ }^{\text {ink4a }}$ [24]. The E6 and E7 oncoproteins of low-risk HPVs have lesser oncogenic potential than those of the high-risk types. Thus E6/E7 proteins seem to be inactivated in low-risk HPV infection, resulting in lower levels of p16 ${ }^{\text {ink4a }}$ immunoexpression. Thus, p16 ${ }^{\text {ink4a }}$ immunoexpression may be distinctive in low- and high-risk HPV infection. The diffuse and strong staining pattern associated with high-grade lesions and the sporadic pattern associated with benign lesions could be attributed to the presence of the low- or high-risk type of HPV. However, some lesions with HPV positivity were $16^{\text {ink4a }}$ negative or sporadically positive, suggesting that the presence of HPV alone does not give rise to $\mathrm{p} 16^{\text {ink4a }}$ positivity and normal function of p16 $6^{\text {ink4a }}$ may also take place in the absence of HPV.

For the detection of nucleic acid sequences, ISH has proven very powerful for revealing gene expression in the morphological context. The integrated HPV genome is detected as a punctuate signal in the nuclei of the infected cells by ISH, whereas the episomal genome is detected as a diffuse signal throughout the nuclei [25-27]. Our results show that ISH yielded sensitive detection of HPV DNA while preserving cervical tissue morphology. Cell morphology was preserved well enough and enabled to distinguish different HPV genotypes. Moreover, cell types which are infected with HPV could be differentiated from those which are not HPV infected. This study did not assess the sensitivity of ISH in tissue sections but the detection of dot-like signals in certain low-grade lesions indicates that ISH is sensitive enough to detect lowcopy DNA in these samples. The potential clinical role of HPV is controversial [28-30], but infection with highrisk HPVs has been associated with progression of cervical lesions to cervical carcinoma [31]. HPV 16 and 18 have consistently been associated with over $90 \%$ of cervical carcinomas and found in $50-80 \%$ of precancerous lesions [32]. Studies using sensitive techniques such as ISH with tyramide signal identification, which identifies the topographical distribution of HPV in cervical biopsies, might offer unique insight into the process of cervical carcinogenesis. The detection of HPV by ISH was considered insensitive and imprecise earlier due to limitations using radioisotopes as well as nonisotopic labels. In any case, the detection limit is reported to be $10-50$ viral copies per cell and the viral copies in HPV-infected cells is mostly $1-10$ copies [27]. This led to the development of more sensitive methods in ISH $[33,34]$. The commercially available ISH detection system used in this study is based on the catalyzed amplification of positive hybridization signals using biotin-tyramide complexes. The same or similar systems are now being used in several studies to identify HPV sequences in cervical lesions with high sensitivity. These systems are capable of detecting single viral copies in routinely fixed material [27].

Association of $\mathrm{p} 16^{\mathrm{ink} 4 \mathrm{a}}$ overexpression to malignant tumors was first reported by Sakaguchi et al. [35] and Sano et al. [7]. Subsequent studies have demonstrated that a negative or low level of p16 ink4a expression is associated with LSIL, whereas p16 ${ }^{\text {ink4a }}$ overexpression is associated with HSIL and cervical cancer $[4,36]$. In the present study, significant overexpression of p16 ${ }^{\text {ink4a }}$ was found in HSIL and invasive cancer samples compared to benign and LSIL samples. A significant association between $16^{\text {ink4a }}$ expression in lesions and high-risk HPV types has also been reported $[6,23]$. Our results showed an association of p16 ink4a overexpression in HSIL and invasive cervical cancer, which were positive for highrisk HPV (type 16/18) DNA, highlighting the possible potential of $16^{\text {ink4a }}$ as a marker for high-risk type HPVrelated lesions and cervical cancer. The detection of p16 overexpression and high-risk HPV signals was useful in predicting the progression of CIN $[37,38]$. Omori et al. [39] observed that similar observations correlate not only with the grade of CIN but also with CIN 2 progression.

In conclusion, we suggest that HPV 16/18 are involved in $16^{\text {ink4a }}$ overexpression associated with HSIL and cervical cancer. Moreover, this study highlights that $\mathrm{p} 16^{\text {ink4a }}$ immunohistochemical evaluation could be useful as a marker for progressive and HPV-related lesions of the uterine cervix. No apparent correlation was found between the presence of HPV and p $16^{\text {ink4a }}$ expression in benign and LSIL, suggesting that HPV itself is not directly 
involved in cell cycle-regulatory pathways that control cervical tumor progression. Further studies are needed to determine whether the viral oncoproteins are involved in the deregulation mechanism of the cell cycle in cervical cancer.

\section{Acknowledgment}

This study was supported by a research grant (No. T 016/ SRS/2006/CSTE) from the Kerala State Council for Science, Technology and Environment, Government of Kerala, India.

\section{References}

1 Schiffman M, Castle PE, Jeronimo J, Rodriguez AC, Wacholder S: Human papillomavirus and cervical cancer. Lancet 2007;370: 890-907.

2 Doorbar J: Molecular biology of human papillomavirus infection and cervical cancer. Clin Sci (Lond) 2006;110:525-541.

- 3 Munger K, Basile JR, Duensing S, Eichten A, Gonzalez SL, Grace M, Zacny VL: Biological activities and molecular targets of the human papillomavirus E7 oncoprotein. Oncogene 2001;20:7888-7898.

-4 Murphy N, Ring M, Killalea AG, et al:p16 $6^{\text {ink4a }}$ as a marker for cervical dyskaryosis: CIN and gCIN in cervical biopsies and ThinPrep smears. J Clin Pathol 2003;56:53-63.

5 Bibbo M, DeCecco J, Kovatich AJ: p16ink4a as an adjunct test in liquid based cytology. Anal Quant Cytol Histol 2003;25:8-11.

6 Klaes R, Friedrich T, Spitkovsky D, Ridder R, Rudy W, Petry U, Dallenbach-Hellweg G, Schmidt D, von Knebel Doeberitz M: Overexpression of $\mathrm{p} 16^{\mathrm{INK} 4 \mathrm{~A}}$ as a specific marker for dysplastic and neoplastic epithelial cells of the cervix uteri. Int J Cancer 2001;92:276284.

7 Sano T, Oyama T, Kashiwabara K, Fukuda T, Nakajima T: Expression status of p16 protein is associated with human papillomavirus oncogenic potential in cervical and genital lesions. Am J Pathol 1998;153:1741-1748.

-8 Parkin DM, Ray F, Ferlay J, Pisani P: Global cancer statistics, 2002. CA Cancer J Clin 2005;55:74-108.

-9 Unger ER: In situ diagnosis of human papillomaviruses. Clin Lab Med 2000;20:289301.

10 Player AN, Shen LP, Kenny D, Antao VP, Kolberg JA: Single copy gene detection using branched DNA (bDNA) in situ hybridization. Histochem Cytochem 2001;49:603612.

11 von Knebel Doeberitz M: New markers for cervical dysplasia to visualize the genomic chaos created by aberrant oncogenic papillomavirus infection. Eur J Cancer 2002;38 2229-2242.

12 Rocco JW, Sidransky D: p16 (MTS-1/ CDKN2/INK4a) in cancer progression. Exp Cell Res 2001;264:42-55.
Esteller M, Gonzalez S, Risques RA, Marcuello E, Mangues R, Germa JR, Herman JG Capella G, Peinado MA: K-ras and p16 aberrations confer poor prognosis in human colorectal cancer. J Clin Oncol 2001;19:299304.

14 Sturm I, Petrowsky H, Volz R, Lorenz M, Radetzki S, Hillebrand T, Wolff G, Hauptmann S, Dorken B, Daniel PT: Analysis of p53/BAX/p16 ink4a/CDKN2 in esophageal squamous cell carcinoma: high $\mathrm{BAX}$ and p16 ink4a/CDKN2 identifies patients with good prognosis. J Clin Oncol 2001;19:22722281.

15 Hayashi N, Sugimoto Y, Tsuchiya E, Ogawa M, Nakamura Y: Somatic mutations of the MTS (multiple tumor suppressor)1/CDK4I (cyclin-dependent kinase-4 inhibitor) gene in human primary non-small cell lung carcinomas. Biochem Biophys Res Commun 1994;202:1426-1430.

16 Fregonesi PA, Teresa DB, Duarte RA, Neto CB, de Oliveira MR, Soares CP: p16 (INK4A) immunohistochemical overexpression in premalignant and malignant oral lesions infected with human papillomavirus. J Histochem Cytochem 2003;51:1291-1297.

$\checkmark 17$ Caldas C, Hahn SA, da Costa LT, Redston MS, Schutte M, Seymour AB, Weinstein CL, Hruban RH, Yeo CJ, Kern SE: Frequent somatic mutations and homozygous deletions of the p16 (MTS1) gene in pancreatic adenocarcinoma. Nat Genet 1994;8:27-32.

18 van de Putte G, Holm R, Lie K, Tropé CG, Kristensen GB: Expression of p27, p21, and p16 protein in early squamous cervical cancer and its relation to prognosis. Gynecol Oncol 2003;89:140-147.

19 Namazie A, Alavi S, Olopade OI, Pauletti G, Aghamohammadi N, Aghamohammadi M, Gornbein JA, Calcaterra TC, Slamon DJ, Wang MB, Srivatsan ES: Cyclin D1 amplification and p16 (MTS1/CDK4I) deletions correlate with poor prognosis in head and neck tumors. Laryngoscope 2002;112:472-481.

20 Takita J, Hayashi Y, Nakajima T, Adachi J, Tanaka T, Yamaguchi N, Ogawa Y, Hanada $\mathrm{R}$, Yamamoto K, Yokota J: The p16 (CDK$\mathrm{N} 2 \mathrm{~A}$ ) gene is involved in the growth of neuroblastoma cells and its expression is associated with prognosis of neuroblastoma patients. Oncogene 1998;17:3137-3143.
1 Straume O, Sviland L, Akslen L: Loss of nuclear p16 protein expression correlates with increased tumor cell proliferation (Ki-67) and poor prognosis in patients with vertical growth phase melanoma. Clin Cancer Res 2000;6:1845-1853.

22 Salvesen H, Das S, Akslen L: Loss of nuclear p16 protein expression is not associated with promoter methylation but defines a subgroup of aggressive endometrial carcinomas with poor prognosis. Clin Cancer Res 2000; 6:153-159.

23 Sano T, Masuda N, Oyama T, Nakajima T: Overexpression of p16 and p14ARF is associated with human papillomavirus infection in cervical squamous cell carcinoma and dysplasia. Pathol Int 2002;52:375-383.

24 zur Hausen H: Papillomaviruses causing cancer: evasion from host-cell control in early events in carcinogenesis. J Natl Cancer Inst 2004;92:690-698.

25 Cooper K, Herrington CS, Stickland JE, Evans MF, McGee JO: Episomal and integrated human papillomavirus in cervical neoplasia shown by non-isotopic in situ hybridization. J Clin Pathol 1991;44:990-996.

-26 Cooper K, Herrington ES, Evans MF, McGee JO: Integration of human papillomavirus types 16 and 18 in cervical adenocarcinoma. J Clin Pathol 1992;45:382-384.

27 Sano T, Hikino T, Niwa Y, Kashiwabara K, Oyama T, Fukuda T, et al: In situ hybridization with biotinylated tyramide amplification: detection of human papillomavirus DNA in cervical neoplastic lesions. Mod Pathol 1998;11:19-23.

28 Manos MM, Kinney WK, Heuley LB, Sherman ME, Shich-Ngai J, Kurman RJ, Ransley JE, Hartinger JS, McIntosh KM, Pawlick GF, Hiati RA: Identifying women with cervical neoplasia: using human papillomavirus DNA testing for equivocal Papanicolaou results. JAMA 1999;281:1605-1610.

29 Bishop JW, Marshall CJ, Bentz JS: New technologies in gynecologic cytology. J Reprod Med 2000;45:701-719.

30 Bovicelli A, Bristow RE, Montz FJ: HPV testing: where are we now? Anticancer Res 2000; 20:4673-4680.

-31 zur Hausen H: Papillomavirus infections - a major cause of human cancers. Biochim Biophys Acta 1996;1288:F55-F78. 
-32 Arends MJ, Buckley CH, Wells M: Aetiology, pathogenesis and pathology of cervical neoplasia. J Clin Pathol 1998;51:96-103.

-33 Birner P, Bachtiary B, Dreier B, Schindle M, Joura EA, Breitenecker G, Oberhuber G: Signal-amplified colorimetric in situ hybridization for assessment of human papillomavirus infection in cervical lesions. Mod Pathol 2001;14:702-709.

34 Kersteins HM, Poddighe PJ, Hanselaar AG: A novel in situ hybridization signal amplification method based on the deposition of biotinylated tyramine. J Histochem Cytochem 1995;43:347-352.
35 Sakaguchi M, Fujii Y, Hirabayashi H, Yoon HE, Komoto Y, Oue T, Kusafuka T, Okada A, Matsuda $\mathrm{H}$ : Inversely correlated expression of p16 and Rb protein in non-small cell lung cancers: an immunohistochemical study. Int J Cancer 1996;65:442-445.

36 Keating JT, Cviko A, Riethdorf S, Riethdorf L, Quade BJ, Sun D, Duensing S, Sheets EE, Munger K, Crum CP: Ki-67, cyclin E, and p16INK4 are complementary surrogate biomarkers for human papilloma virus-related cervical neoplasia. Am J Surg Pathol 2001;25: 884-891.

>37 Guimarães MCM, Gonçalves MAG, Soares CP, Bettini JSR, Duarte RA, Soares EG: Immunohistochemical expression of p16INK4a and bcl-2 according to HPV type and to the progression of cervical squamous intraepithelial lesions. J Histochem Cytochem 2005; 53:509-516.
38 Kalof AN, Evans MF, Simmons-Arnold, Linda BS, Barbara BG, Cooper K: p16INK4A immunoexpression and HPV in situ hybridization signal patterns: potential markers of high-grade cervical intraepithelial neoplasia. Am J Surg Pathol 2005;29:674-679.

39 Omori M, Hashi A, Nakazawa K, Yuminamochi T, Yamane T, Hirata S, Katoh R, Hoshi $\mathrm{K}$ : Estimation of prognoses for cervical intraepithelial neoplasia 2 by pl6INK4a immunoexpression and high risk HPV in situ hybridization signal types. Am J Clin Pathol 2007;128:208-217. 